\title{
KAJIAN HUKUM NORMATIF TERHADAP SANKSI ADMINISTRASI NEGARA DALAM QANUN KOTA BANDA ACEH Apri Rotin Djusfi Email:apri.rotin@yahoo.com
}

\begin{abstract}
The development of Indonesia state administration law is indicated when the government manage the people by using the law order with determine the decision about prohibition or by the issuance of permit system. Quanun based on the Law of Aceh Government is "Regulations in local regulations that rule the government administration and the society living of local area in Aceh.

Generally, the type and several of sanctions is recorded and determine clearly in the administration rule. There are any sanction in administration law, i.e. government coercion, withdraw the advantage decision (subsidy permit, payment), coercion fee by government, and administration fine. The policy on concept of administration sanction in Quanun according to the description of Act No. 11 of 2006 concerning to Aceh Government indicates that Quanun is a rule that override the other rules by follow the principles of Lex Specialis derogaat Lex Generalis. Asrticle 18 of Constitution of 1945 is a law base for the implementation of local autonomy by provides the local head with wide authority, real and accountable.
\end{abstract}

Keyword : Development, Law, Panismen, Local Goverment

\begin{abstract}
Abstrak
Pembangunan hukum tata negara Indonesia menunjukkan ketika pemerintah mengatur masyarakat dengan menggunakan tata tertib hukum dengan menentukan keputusan tentang larangan atau penerbitan sistem perizinan. Qanun berdasarkan Hukum Pemerintah Aceh adalah regulasi dalam perda yang mengatur administrasi pemerintahan dan kehidupan masyarakat lokal di Aceh.

Pada umumnya, tipe dan beberapa sanksi direkam dan menentukan dengan jelas dalam aturan administrasi. Ada beberapa sanksi dalam hukum administrasi misalnya paksaan pemerintah, pengambilan keputusan ( izin subsidi, pembayaran), biaya paksaan oleh pemerintah, dan denda administrasi. Kebijakan pada konsep sanksi administrasi dalam Qanun berdasarkan deskripsi UU Nomor 11 tahun 2006 tentang pemerintahan Aceh menunjukkan bahwa Qanun adalah suatu aturan yang mengesampingkan aturan-aturan lain batas dengan mengikuti prinsip-prinsip lex specialis derogaat generalis lex pasal 18 dari konstitusi 1945 adalah sebuah basis hukum unuk implementasi otonomi lokal oleh ketersediaan kepala dengan wewenang yang luas, nyata dan akuntabel.
\end{abstract}

Kata Kunci : Pembangunan, Hukum, Sangksi, Pemerintah Daerah 


\section{A. PENDAHULUAN}

\section{Latar Belakang}

Perkembangan hukum administrasi telah berkembang dalam suasana manakala pihak Pemerintah mulai menata masyarakat dan dalam kaitan itu menggunakan sarana hukum, umpamanya dengan menetapkan keputusankeputusan larangan tertentu atau dengan menerbitkan sistem-sistem perizinan, Philipus M. Hadjon (2001 hal 29) . Aceh terletak di ujung utara pulau Sumatera dan paling barat kepulauan Nusantara, Mohhamad Said (2007).

Dalam catatan sejarah, Aceh dapat dikatakan sebagai daerah yang tidak pernah lepas dari konflik. Pasca-kemerdekaan Indonesia, konflik antara Aceh dan Pemerintah Pusat pertama kali terjadi pada saat gerakan Darul Islam (DI/TII) pimpinan Tengku Daud Bereueh diproklamasikan pada Tahun 1953. Pemberontakan ini dipicu oleh kebijakan pemerintah pusat untuk melebur Provinsi Aceh ke dalam Provinsi Sumatera Utara, yang membawa konsekuensi dihapusnya hak istimewa bagi masyarakat Aceh untuk menjalankan syari'at Islam dalam kehidupan masyarakat dan pemerintahan M. Hmadan Bahsyar et al (2008 hal. Vii)..

Hingga akhirnya pada tanggal 15 Agustus 2005 Pemerintah Indonesia dan Gerakan Aceh Merdeka menegaskan komitmen mereka untuk penyelesaian konflik Aceh secara damai, menyeluruh, berkelanjutan dan bermartabat bagi semua. Para pihak bertekad untuk menciptakan kondisi sehingga pemerintahan rakyat aceh dapat diwujudkan melalui suatu proses yang demokratis dan adil dalam Negara kesatuan dan Konstitusi Republik Indonesia.

Nota kesepahaman merinci isi persetujuan yang dicapai dan prinsipprinsip yang akan memandu proses transformasi. Untuk maksud ini Pemerintah Indonesia dan Gerakan Aceh Merdeka menyepakati hal-hal, salah satunya adalah mengenai Qanun Aceh. Di dalam nota kesepahaman dikatakan Qanun Aceh akan disusun kembali untuk Aceh dengan menghormati tradisi sejarah dan adat istiadat rakyat Aceh serta mencerminkan kebutuhan hukum terkini, Aceh MoU Aceh- RI (2005).

Terjadinya plurarisme hukum disebabkan tidak mungkinnya sesuatu aturan hukum diberlakukan kepada seluruh masyarakat secara seragam, karena latar belakang perbedaan yang terdapat di dalam kehidupan masyarakat itu. Hal semacam ini secara universal adalah merupakan sesuatu 
yang lazim dalam setiap sistem hukum nasional Negara masing-masing. Undang-Undang Dasar 1945 sendiri memungkinkan terciptanya plurarisme hukum. Ketentuan Pasal 18B UUD 1945 (Undang-Undang Dasar 1945) :

1. Negara mengakui dan menghormati satuan-satuan pemerintahan daerah yang bersifat khusus atau bersifat istimewa yang diatur dengan Undang-undang.

2. Negara mengakui dan menghormati kesatuan-kesatuan masyarakat hukum adat beserta hak-hak tradisionalnya sepanjang masih hidup dan sesuai dengan perkembangan masyarakat dan prinsip NKRI yang diatur dengan Undang-Undang.

Perumusan dan pelaksanaan syari'at islam melalui Qanun Aceh merupakan fiqih Aceh. Ketentuan-ketentuan yang terdapat dalam Qanun Aceh bersumber pada Al-Qur'an dan hadis Nabi Saw Madiasa Ablisar (Hal 10) . Pengertian Qanun berdasarkan ketentuan Undang-undang tentang Pemerintah Aceh adalah "peraturan perundang-undangan sejenis peraturan daerah kabupaten/kota yang mengatur penyelenggaraan pemerintahan dan kehidupan masyarakat kabupaten/kota di Aceh" (Undang Undang Nomor 11 tahun 2006).

\section{Permasalahan}

Berdasarkan uraian latar belakang tersebut di atas, permasalahan dalam penulisan tesis ini adalah sebagai berikut :

1. Bagaimana pengaturan sanksi administrasi pada Qanun Kota Banda Aceh?

2. Bagaimana konsep ketentuan sanksi administrasi pada Qanun Kota Banda Aceh?

3. Bagaimana wewenang penetapan sanksi administrasi Qanun Kota Banda Aceh?

\section{Tujuan Penelitian}

Terkait dengan judul dan permasalahan yang dikemukakan dalam penelitian ini yang menitikberatkan pada penerapan aspek administrasi pada Qanun Kota Banda Aceh, maka tujuan penelitian ini sebagai berikut :

1. Untuk mengetahui dan menganalisis pengaturan sanksi administrasi pada Qanun.

2. Untuk mengetahui serta menganalisis konsep ketentuan sanksi administrasi pada Qanun. 
3. Untuk mengetahui serta menganalisis mengenai wewenang penetapan sanksi administrasi pada Qanun.

\section{Manfaat Penelitian}

Diharapkan penelitian ini dapat memberikan manfaat baik yang bersifat praktis maupun teoritis.

Hasil penelitian ini dalam aspek teoritis, diharapkan dapat memberikan kontribusi pemikiran serta pemahaman dan pandangan baru serta dapat menjadi bahan kajian lebih lanjut untuk melahirkan konsep-konsep ilmiah yang ada. Dengan penelitian ini juga diharapkan dapat memperkaya pemahaman akademisi di bidang ilmu hukum, khususnya hukum administrasi, serta menambah khasanah kajian Tata Negara di bidang Pemerintahan Daerah.

Manfaat dari segi praktis, diharapkan penelitian dapat memberikan sumbangan pemikiran bagi pembuat kebijakan di Pemerintahan Daerah dalam merumuskan peraturan daerah terutama penerapan aspek administrasi pada peraturan daerah. Bagi para penegak hukum diharapkan penelitian ini dapat menjadi bahan masukan dalam menentukan kebijakan serta langkah-langkah penanganan dan penyelesaian perkara-perkara yang berkaitan dengan sanksi administrasi pada peraturan daerah.

\section{B. Kerangka Teori}

Secara konseptual, teori yang dapat dijadikan acuan adalah dengan mempergunakan beberapa teori yakni, Teori Pembentukan Undang-undang dan Teori Desentralisasi. Sehubungan dengan jamaknya problematika dalam proses pembentukan undang-undang, para sarjana Belanda (Dutch Scholars) kemudian mengembangkan pemikiran tentang pembentukan undang-undang yang efektif, agar tujuan pembentukan undang-undang dapat tercapai. Beberapa teori tentang pembentukan undang-undang (theories of lawmaking), diantaranya ialah yang dikemukakan oleh Jan Michiel Otto dan kawan-kawan.

Pemikiran Otto dan kawan-kawan, mencoba mengarahkan teori pembentukan undang-undang kepada "the socio-legal concept of real legal certainty". Di dalamnya terdiri atas lima elemen pencapaian kepastian hukum yang nyata, yaitu :

1. Seorang penyusun undang-undang telah menegaskan secara, dapat diakses dan realistis (a lawmaker has laid down clear, accessible and realistic rules).

2. Pemerintah menjalankan aturan-aturan yang telah disusun dan memerintahkan warganya untuk menjalankan hal yang sama (the 
administration follows these rules and induces citizens to do the same).

3. Mayoritas orang menerima aturan ini, secara prinsip, dan berkeadilan (the majority of people accept these rules, in principle, as just).

4. Konflik serius secara teratur dibawa ke hadapan hakim independen dan imparsial yang memutuskan kasus-kasus sesuai dengan aturanaturan (serious conflicts are regularly brought before independent and impartial judges who decide cases in accordance with those rules).

5. Keputusan ini sebenarnya sesuai dengan bagaimana mendefinisikan tujuan-tujuan hukum dan proyek pembangunan yang dapat membantu meningkatkan efektivitas mereka (these decisions are actually complied with defining objectives of law and development projects in these terms could help improving their effectiveness).

Menurut Otto, teori pembentukan undang-undang memungkinkan untuk mengenali faktor-faktor relevan yang mempengaruhi kualitas hukum dan substansi undang-undang. Teori-teori tersebut meliputi :

1. Teori kebijakan fase sinoptik (the synoptic policy-phases theory).

2. Teori membangun agenda (the agenda-building theory).

3. Teori elit ideology (the elite ideology theory).

4. Teori biro politik organisasi dan politik teori (the bureau-politics theory organisational politics theory).

5. Keempat teori rasionalitas (the four rationalities theory).

Di antara kelima macam teori pembentukan undang-undang tersebut, "the agenda-building theory" kiranya sesuai memiliki kesamaan dengan situasi dan kondisi pembentukan hukum di Indonesia, yang pada umunya memiliki karateristik "a bottom up approach”.

Dengan demikian, "the agenda-building theory" mengandung persamaan unsur-unsur dengan proses pembentukan undang-undang di Indonesia. Berkaitan dengan hal tersebut, dapat dicermati bahwa banyaknya perangkat Rancangan Undang-Undang(RUU) yang masuk daftar Progam Legislasi Nasioanal (Prolegnas 2005-2009), namun diantaranya terdapat RUU yang terkesan tidak memiliki relevansi dan terjadi tumpang tindih pengaturan satu dengan lainnya, tanpa adanya agenda yang jelas, dan sinergis satu sama 
lain. Contohnya tumpang tindih antara RUU Kelautan dan RUU Pesisir yang diprakarsai oleh pemerintah (Departemen Kelautan dan Perikanan) (UndangUndang Nomor 11 Tahun 2006).

Selanjutnya yang diuraikan oleh Yuliandri di dalam bukunya yang berjudul "Asas-Asas Pembentukan Peraturan Perundang-undangan Yang Baik" bahwa proses pembentukan Undang-undang perlu mewujudkan asasasas pembentukan peraturan perundang-undangan yang baik. Asas-asas tersebut diperlukan sebagai pedoman dalam pelaksanaan tahapan pembentukan Undang-undang. Di dalamnya termasuk tahap perencanaan, persiapan, teknik penyusunan, perumusan, pembahasan, pengesahan, pengundangan dan penyebarluasan (Undang-Undang Nomor 11 Tahun 2006).

Secara etimologi istilah desentralisasi berasal dari bahasa Latin, yaitu "de" berarti lepas dan "centrum" berarti pusat. Jadi menurut perkataan berasal dari desentralisasi adalah melepaskan dari pusat Juanda (2004 hal 117).

Desentralisasi dan otonomi daerah adalah suatu peristiwa yang menimbulkan perubahan mendasar pada hubungan antara pemerintah pusat dan daerah, sekaligus mengubah perilaku sebagian masyarakat Indonesia yang sebelumnya hanya berfokus pada satu pusat kekuasaan yaitu pemerintah pusat.

Desentralisasi memang tidak mempunyai suatu definisi yang tunggal. Apapun definisi desentralisasi yang dipilih, harus terjadi harmonisasi yang baik antara desentralisasi politik, administrasi, dan fiscal. Desentralisasi politik pada intinya memberikan kewenangan kepada pemerintah daerah untuk menjalankan suatu kebijakan, sedangkan desentralisasi administrasi atau desentralisasi manajerial memberikan petunjuk bagaimana implementasi dari pengalihan kewenangan fungsi tersebut. Desentralisasi fiskal kemudian menyediakan pembiayaan untuk pengalihan kewenangan tersebut.

\section{HASIL PENELITIAN}

\section{C.I. Pengaturan Sanksi Administrasi Dalam Qanun}

\section{Pengaturan Sanksi Administrasi Dalam Qanun Ditinjau Dari} Hukum Administrasi Pemerintahan Islam

Administrasi pemerintahan termasuk di dalam As-Sultah atTanfiziyyah yaitu kekuasaan atau wewenang melaksanakan atau menjalankan sesuatu urusan. Kekuasaan atau wewenang pemerintah untuk melaksanakan dan menjalankan roda pemerintahan serta (kekuasaan legislatif) dan kekuasaan eksekutif Negara. Administrasi pemerintahan juga berhubungan 
dengan Siyasah Syar'iyyah yaitu pembahasan yang menyangkut permasalahan kekuasaan, fungsi dan tugas penguasa dalam pemerintahan islam, Saiful Anwar dan Marzuki Lubis (2004 hal 137).

Menurut Abdul Wahhab Khailaf, Abdul Azis Dahlan et al (1996 hal 1626), dalam pemerintahan islam penguasa memiliki wewenang mengatur kepentingan umum untuk mencapai kemaslahatan dan terhindar dari segala kemudratan, dalam batas-batas yang ditentukan oleh syarat dan kaidah-kaidah umum yang berlaku sekalipun upaya ini tidak sejalan dengan "ijtihad ulama". Kepentingan umum yang dimaksudkan adalah segala peraturan dan perundang-undangan Negara, baik yang berkaitan dengan hubungan Negara dengan rakyat maupun hubungan Negara dengan Negara lain.

\section{Pola Jenis Sanksi Dalam Hukum Administrasi Negara}

Seiring denga luasnya ruang lingkup dan keragaman bidang urusan pemerintahan yang masing-masing bidang itu diatur dengan peraturan tersendiri, macam dan jenis sanksi dalam rangka penegakan peraturan itu beragam. Pada umunya macam-macam dan jenis sanksi itu dicantumkan dan ditentukan secara tegas dalam peraturan perundang-undangan bidang administrasi tertentu. Secara umum dikenal beberapa macam sanksi dalam hukum administrasi, yaitu :

1. Paksaan pemerintahan (bestuursdwang)

2. Penarikan kembali keputusan yang menguntungkan (izin subsidi, pembayaran, dan sebagainya)

3. Pengenaan uang paksa oleh pemerintah (dwangsom)

4. Pengenaan denda administrasi (administratieve boete)

Macam-macam sanksi tersebut tidak selalu dapat diterapkan secara keseluruhan pada suatu bidang administrasi Negara tertentu. Sanksi paksaan pemerintahan misalnya, sudah barang tentu tidak dapat diterapkan dalam bidang kepegawaian dan ketenagakerjaan. Akan tetapi, dapat terjadi dalam suatu bidang administrasi diterapkan lebih dari kempat macam sanksi tersebut, seperti dalam bidang lingkungan, Siti Sundari Rangkuti (1996 hal 192-193).

Pemahaman terhadap berbagai sanksi tersebut di atas penting dalam kajian hukum administrasi karena di dalamnya menyangkut bukan saja tentang efektifitas penegakan hukum, bagaimana pemerintah menggunakan kewenangannya dalam menerapkan sanksi, dan prosedur penerapan sanksi, tetapi juga untuk mengukur apakah norma-norma hukum administrasi yang 
didalamnya memuat sanksi telah sesuai dibuat dan relevan diterapkan di tengah masyarakat.

\section{Pengaturan Sanksi Administrasi Ditinjau Dari Tujuan Administrasi}

Penerapan administrasi dalam zaman modern sekarang ini yang dipentingkan bukan hukum administrasi akan tetapi administrasinya dan tercapainya tujuan dari administrasi. Ivon Jennings mengatakan bahwa hukum administrasi itu adalah hukum yang mengenai administrasi.

Menurut A.M. Donner apabila kita hendak mempelajari hukum administrasi perlu kita memahami dahulu apa bestuur atau administrasi itu. Sedangkan menurut JHA. Logemann menonjolkan administrasi sebagai suatu organisasi kekuasaan bukan hukum yang diutamakan. Hukum itu adalah alat menjadi tujuan tersendiri, akan tetapi hukum itu adalah alat belaka untuk mempermudah lalu lintas antar manusia Amran Muslimin (1985 hal 35). Dalam pergaulan hidup manusia dibutuhkan kerja sama dan kerja sama ini membutuhkan suatu perasaan kepastian dan aturan-aturan yang dapat dipegang. Dapat disimpulkan tujuan hukum administrasi Negara adalah :

1. Memberikan batasan dan kewenangan terhadap pejabat administrasi Negara.

2. Memberikan perlindungan terhadap rakyat atau badan hukum perdata dari tindakan sewenang-wenang pejabat administrasi Negara.

\section{C.II. Konsep Ketentuan Sanksi Administrasi Pada Qanun}

\section{Kedudukan Qanun}

Undang-Undang Nomor 11 Tahun 2006 tentang Pemerintahan Aceh merupakan tatanan hukum dalam sistem hukum dan sistem perundangundangan nasional. Dalam Pasal 1 angka 21 Undang-Undang No.11 Tahun 2006, ditentukan bahwa "Qanun Aceh adalah peraturan perundang-undangan sejenis peraturan daerah provinsi yang mengatur penyelenggaraan pemerintahan dan kehidupan masyarakat Aceh." Dalam Pasal 233 ayat (1) ditentukan bahwa "qanun dibentuk dalam rangka penyelenggaraan Pemerintahan Aceh, pemerintahan kabupaten/kota, dan penyelenggaraan tugas pembantuan."

Undang-Undang No. 32 Tahun 2004 Tentang Pemerintah Daerah, dalam Pasal 136 ayat (2) ditegaskan bahwa "peraturan daerah dibentuk dalam rangka penyelenggaraan otonomi daerah provinsi/kabupaten/kota dan tugas 
pembantuan." Pada ayat (3) pasal yang sama ditentukan lebih lanjut bahwa peraturan daerah merupakan penjabaran lebih lanjut dari peraturan perundangundangan yang lebih tinggi dengan memperhatikan ciri khas masing-masing daerah.

Dalam Pasal 1 angka 8 Undang-Undang No. 12 Tahun 2011 Tentang Pembentukan Peraturan Perundang-undangan ditentukan bahwa "peraturan daerah kab/kota adalah peraturan perundang-undangan yang dibentuk oleh Dewan Perwakilan Rakyat Daerah Kab/Kota dengan persetujuan bersama Bupati/Walikota." Kemudian dalam Pasal 14 Undang-Undang Nomor 12 Tahun 2011 Tentang Pembentukan Peraturan Perundang-undangan ditentukan bahwa "materi muatan peraturan daerah provinsi/kota adalah seluruh materi muatan dalam rangka penyelenggaraan otonomi daerah dan tugas pembantuan, serta menampung kondisi khusus daerah dan atau penjabaran lebih lanjut peraturan perundang-undangan yang lebih tinggi."

Dapat disimpulkan bahwa Qanun merupakan salah satu bentuk hukum tertulis dalam sistem perundang-undangan nasional, yang sejenis dengan Peraturan Daerah. Numum secara khusus isinya berbeda, oleh karena kewewenangan mengatur dan materi muatan tertentu dalam qanun didasarkan pada ketentuan dalam Undang-Undang No. 11 Tahun 2006. Sedangkan materi muatan "peraturan daerah" yang secara umum berpedoman pada ketentuan Undang-Undang No. 32 Tahun 2004.

Pemerintah Aceh berdasarkan ketentuan Undang-Undang No. 11 Tahun 2006 mempunyai kewewenang spesifik untuk mengatur beberapa hal tertentu sebagai materi muatan qanun, misalnya tentang pelaksanaan syari'at Islam. Kewenangan ini secara hukum adalah sah, sebagai kewenangan atribusi (attributie van bevoegheid), yang diciptakan atau dibentuk oleh pembentuk undang-undang (DPR), yang sebelumnya tidak ada, dan secara khusus diadakan untuk itu.

Dengan demikian Qanun merupakan bagian dari sistem perundangundangan nasional, dan oleh karena itu norma atau kaedah hukum yang diatur atau materi muatan dalam Qanun merupakan sub sistem dari sistem hukum nasional. Disebut "sub sistem" oleh karena wilayah berlakunya adalah khusus atau bersifat lokal. Walaupun berlakunya pada wilayah khusus akan tetapi penegakan hukumnya tetap melibatkan institusi dalam sistem peradilan nasional (Undang-Undang Nomor 32 Tahun 2004). 
Dalam sistem peraturan perundang-undangan, bahwa secara hukum kedudukan atau eksistensi qanun sangat jelas, merupakan bagian dari sistem perundang-undangan nasional.

\section{Tujuan Dan Fungsi Qanun}

Qanun sebagai peraturan perundang-undangan daerah dibuat untuk menyelenggarakan urusan pemerintahan Aceh. Qanun tersebut merupakan bagian yang tak terpisahkan dari kesatuan sistem perundang-undangan nasional. Sistem perundang-undangan Republik Indonesia diatur dalam tata urutannya menurut ketentuan Pasal 7 ayat (1) Undang-Undang Nomor 12 Tahun 2011 Tentang Pembentukan Peraturan Perundang-undangan, ditegaskan bahwa jenis dan hirarki peraturan perundang-undangan adalah, (Undang-Undang Nomor Nomor 12 Tahun 2011):

a. UUD.

b. Ketetapan MPR.

c. Undang-Undang/Perpu.

d. Peraturan Pemerintah.

e. Peraturan Presiden.

f. Peraturan Daerah Provinsi.

g. Peraturan Daerah Kabupaten/Kota

Mengenai qanun sebagai jenis peraturan perundang-undangan untuk penyelenggaraan pemerintahan Aceh tidak disebutkan dalam Pasal 7 ayat (1) Undang-undang Nomor 12 Tahun 2011 Tentang Pembentukan Peraturan Perundang-undangan. Akan tetapi keberadaan Qanun dapat dilihat atau ditelusuri dalam sumber hokum yang utama, yakni Pasal 18B UndangUndang Dasar 1945.

Peraturan Daerah, untuk Provinsi Nanggroe Aceh Darussalam disebut dengan Qanun. Hal ini ditegaskan dalam Pasal 30 Undang-undang Nomor 18 Tahun 2001 Tentang Otonomi Khusus Bagi Provinsi Daerah Istimewa Aceh Sebagai Provinsi Nanggroe Aceh Darussalam, yang sudah dicabut dengan Undang-undang Nomor 11 Tahun 2006 Tentang Pemerintahan Aceh, ditetapkan bahwa "semua peraturan daerah yang ada dinyatakan sebagai Qanun Provinsi Nanggroe Aceh Darussalam sesuai dengan yang dimaksud dengan undang-undang ini".

Dalam penjelasan umum Undang-undang Nomor 11 Tahun 2006 Tentang Pemerintahan Aceh menyebutkan bahwa Qanun Provinsi Nanggroe Aceh Darussalam, yang dapat mengenyampingkan peraturan perundang- 
undangan yang lain dengan mengikuti asas Lex Specialis Derogaat Lex Generalis dan Mahkamah Agung berwenang melakukan uji materil terhadap Qanun, Mohd. Daud Yoesoef (2009 hal 181). Keterkaitan dengan tata urutan perundang-undangan menurut Undang-undang Nomor 12 Tahun 2011 diatas, maka telah menempatkan "Qanun" sebagai subsistem perundang-undangan nasional bahkan sistem hukum nasional pada umumnya. Karena itu Qanun tidak boleh bertentangan dengan peraturan perundang-undangan yang lebih tinggi tingkatnya, Bagir Manan (1995 hal 9 ).

Dari uraian di atas dapat dipahami bahwa Qanun Provinsi Nanggroe Aceh Darussalam berfungsi sebagai berikut:

a. Menyelenggarakan pengaturan hal-hal yang tidak bertentangan dengan peraturan perundang-undangan yang lebih tinggi (peraturan perundang-undangan tingkat pusat).

b. Menyelenggarakan pengaturan hal-hal yang belum diatur oleh peraturan perundang-undangan yang lebih tinggi. Fungsi ini memperjelas ketentuan yang diatur dalam Pasal 270 ayat (1) ayat (2) dan (3) Undang-undang Nomor 11 Tahun 2006 Tentang Pemerintahan Aceh yang menetapkan bahwa "ketentuan pelaksana undang-undang ini yang menyangkut kewenangan pemerintah ditetapkan dengan peraturan perundang-undangan (peraturan pemerintah), dan ketentuan yang menyangkut kewenangan pemerintah provinsi dan kabupaten/kota Nanggroe Aceh Darussalam ditetapkan dengan Qanun.

Sedangkan beberapa pakar hukum juga mengemukakan tujuan dan fungsi dari Qanun adalah sebagai berikut :

a. Melaksanakan perintah Undang-undang Nomor 11 Tahun 2006 Tentang Pemerintah Aceh.

b. Fungsinya untuk mengisi kekosongan hukum di daerah dalam rangka pelaksanaan otonomi daerah.

Kedudukan Qanun sesuai dengan penyelenggaraan otonomi khusus bagi Provinsi Nanggroe Aceh Darussalam perlu makin dikukuhkan kedudukannya yang dapat bersifat mandiri, dari segi pembuatannya sudah semestinya kedudukan Qanun ini dapat dilihat setara dengan Undang-undang dalam arti sama-sama merupakan produk hukum lembaga legislatif, namun demikian dari segi pengaturan materi dalam ruang lingkup daerah yang berlaku di wilayah yang lebih sempit, maka dianggap mempunyai kedudukan 
lebih rendah dibandingkan dengan ruang lingkup wilayah berlakunya undangundang.

Undang-undang lebih tinggi kedudukannya dari pada Qanun. Karena itu sesuai prinsip hirarki peraturan perundang-undangan, peraturan yang lebih rendah itu tidak boleh bertentangan dengan peraturan yang derajatnya lebih tinggi. Akan tetapi, sebagai konsekuensi diberikannya otonomi khusus bagi provinsi Naggroe Aceh Darussalam maka produk legislatif daerah ini dapat saja menyimpang dengan produk eksekutif di tingkat pusat. Misalnya suatu materi qanun/perda yang telah ditetapkan secara sah ternyata bertentangan isinya dengan materi peraturan menteri di tingkat pusat maka pengadilan haruslah menertibkan bahwa qanun itulah yang berlaku sepanjang untuk daerahnya sedangkan peraturan Menteri dimasudkan untuk peraturan yang berlaku umum di seluruh Indonesia.

\section{Konsep Sanksi Administrasi Pada Qanun}

Kebijakan untuk konsep sanksi administrasi dalam qanun menurut penejelasan Undang-undang Nomor 11 Tahun 2006 Tentang Pemerintahan Aceh menyebutkan Qanun adalah peraturan yang dapat mengeyampingkan peraturan perundang-undangan yang lain dengan mengikuti asas Lex Specialis derogaat Lex Generalis. Kedudukan Qanun sesuai dengan penyelenggaraan otonomi khusus bagi Provinsi Nanggroe Aceh Darussalam yang dapat bersifat mandiri. Sebagai konsekuensi diberikannya otonomi khusus kepada Aceh maka produk legislatif daerah ini dapat saja menyimpang dengan produk eksekutif di tingkat pusat. Misalnya suatu materi qanun yang telah ditetapkan secara sah ternyata bertentangan isinya dengan materi peraturan menteri di tingkat pusat maka pengadilan haruslah menertibkan bahwa qanun itulah yang berlaku sepanjang untuk daerahnya sedangkan peraturan menteri dimaksudkan untuk peraturan yang berlaku umum diseluruh Indonesia.

\section{Perbedaan Peraturan Daerah Dan Qanun}

\section{a. Peraturan Daerah.}

Peraturan perundang-undangan tingkat daerah diartikan sebagai peraturan peraturan perundang-undangan yang dibentuk oleh pemerintah daerah atau salah satu unsur pemerintah daerah yang berwenang membuat peraturan perundang-undangan daerah.

Peraturan daerah (perda) ditetapkan oleh kepala daerah setelah mendapatkan persetujuan bersama Dewan Perwakilan Rakyat, (UndangUndang Nomor 32 Tahun 2004)(. Ketentuan ini mengikuti semangat rumusan UUD 1945 Pasal 5 ayat (1) yang menyebutkan "Presiden memegang 
kekuasaan membentuk undang-undang dengan persetujuan Dewan Perwakilan Rakyat". Dengan demikian dapat diartikan bahwa Peraturan Daerah itu semacam undang-undang (pada tingkat daerah).

Meskipun Undang-undang menyebutkan bahwa Kepala Daerah menetapkan Peraturan daerah setelah mendapat persetujuan Dewan Perwakilan Rakyat Daerah, tidak berarti semua kewenangan membuat peraturan daerah ada pada kepala daerah dan Dewan Perwakilan Rakyat Daerah hanya memberikan persetujuan. Dewan Perwakilan Rakyat Daerah memiliki kekuasaan yang juga menentukan dalam pembentukan peraturan daerah. DPRD dilengkapi dengan hak-hak inisiatif dan hak mengadakan perubahan. Bahkan persetujuan itu sendiri mengandung kewenangan menentukan (dicicive). Tanpa persetujuan DPRD tidak akan ada peraturan daerah. Karena itulah tidak berlebihan kalau Pasal 136 Undang-undang Nomor 32 Tahun 2004 Tentang Pemerintah Daerah ditentukan “ pembuatan peraturan daerah dilakukan bersama-sama oleh Kepala Daerah dan Dewan Perwakilan Daerah", Abdul Latief (2005 hal 59).

Peraturan Daerah dibentuk berdasarkan asas pembentukan peraturan perundang-undangan yang meliputi HAW Widjaja (2005 hal 244):

1. Kejelasan tujuan

2. Kelembagaan atau organ pembentuk yang tepat

3. Kesesuaian antara jenis

4. Dapat dilaksanakan

5. Kedayagunaan dan kehasilgunaan

6. Kejelasan rumusan

7. Keterbukaan

Sedangkan materi muatan dalam Peraturan Daerah mengandung asas sebagai berikut:

1. Pengayoman

2. Kemanusiaan

3. Kebangsaan

4. Kekeluargaan

5. Kenusantaraan

6. Bhineka tunggal ika

7. Keadilan

8. Kebersamaan kedudukan dalam hukum dan pemerintahan

9. Ketertiban dan kepastian hukum

10. Keseimbangan, keselarasan dan keserasian 
Selanjutnya ada beberapa daerah yang memiliki Perda Syariah dimana tujuan dari pembentukan Peraturan Daerah tersebut untuk menciptakan masyarakat yang mencintai budaya islam dan adat istiadat daerah tersebut. Di dalam penerapan sanksinya Perda Syariah menerapkan sanksi administrasi, dimana sanksi dari pelanggaran Perda Syariah dikenakan teguran secara lisan dan tulisan. Sebagai contoh Perda No 6 Tahun 2005 Tentang Berpakaian Muslim dan Muslimah Kabupaten Solok Selatan. Di dalam penjelasan Pasal 3 Perda No 6 Tahun 2005 Tentang Berpakaian Muslim dan Muslimah Kabupaten Solok Selatan menyatakan, Peraturan Daerah (Nomor 6 Tahun 2005):

1. Membentuk sikap sebagai seorang muslim dan muslimah yang baik dan beraklhak mulia.

2. Membiasakan diri berpakaian muslim dan muslimah dalam kehidupan sehari-hari baik dalam kehidupan bekeluarga maupun dihadapan umum.

3. Menciptakan masyarakat yang mencintai budaya islam dan budaya minangkabau

4. Melestarikan fungsi adat sesuai dengan pituah "syara mangato adat mamakai".

Di dalam Pasal 5 Perda Nomor 6 Tahun 2005 Tentang Berpakaian Muslim dan Muslimah di Kabupaten Solok Selatan, dijelaskan kewajiban dan pelaksanaan. Menurut ketentuan Pasal 5 Perda Nomor 6 Tahun 2005 Tentang Berpakaian Muslim dan Muslimah yang berkewajiban berbusana muslim dan muslimah hanya pelajar baik di tingkat SD,SMP,SMU dan karyawan/karyawati, sedangkan mahasiswa/mahasiswi, TNI dan POLRI dan masyarakat umum bersifat himbauan.

Dalam uraian tersebut maka dapat disimpulkan bahwa Peraturan Daerah dibuat karena ada perintah dari Undang-undang Nomor 12 Tahun 2008 Tentang Perubahan Kedua atas Undang-undang Nomor 32 Tahun 2004 Tentang Pemerintah Daerah dan juga Undang-undang Nomor 12 Tahun 2011 Tentang Pembentukan Peraturan Perundang-undangan.

\section{b. Qanun}

Qanun adalah peraturan perundang-undangan sejenis peraturan daerah yang mengatur penyelengaaraan pemerintahan dan kehidupan masyarakat Aceh. Sedangkan Qanun kabupaten/kota adalah peraturan perundangundangan sejenis peraturan daerah kabupaten/kota yang menyelenggarakan 
pemerintahan dan kehidupan masyarakat kabupaten/kota di Aceh, (UU Nomor 11 Tahun 2006) .

Undang-undang Nomor 11 Tahun 2006 Tentang Pemerintahan Aceh dalam Pasal 237 ayat (1) menentukan bahwa untuk membentuk qanun harus mengandung asas (UU Nomor 11 Tahun 2006) :

1. Pengayoman

2. Kemanusiaan

3. Kebangsaan

4. Kekeluargaan

5. Keanekaragaman

6. Keadilan

7. Nondiskriminasi

8. Kebersamaan kedudukan dalam hukum dan pemrintahan

9. Ketertiban

10. Kepastian hukum

11. Keseimbangan, keserasian, kesetaraan dan keselarasan.

Qanun Aceh disahkan oleh kepala daerah dalam hal ini Gubernur setelah mendapatkan persetujuan bersama Dewan Perwakilan Rakyat Aceh selanjutnya Qanun Kabupaten/Kota disahkan oleh kepala daerah dalam hal ini Bupati/Walikota setelah mendapatkan persetujuan bersama Dewan Perwakilan Rakyat Kota. Mengenai Qanun sebagai jenis peraturan perundangundangan untuk penyelenggaraan pemerintahan aceh tidak disebutkan dalam Undang-undang Nomor 12 Tahun 2011 Tentang Pembentukan Peraturan Perundang-undangan. Akan tetapi keberadaan Qanun dapat ditelusuri dalam sumber hukum yang utama, yakni Pasal 18B UUD 1945. Qanun Aceh adalah peraturan daerah Provinsi Nanggroe Aceh Darussalam, yang dapat mengenyampingkan peraturan perundang-undangan yang lain dengan mengikuti asas Lex specialis derogate Lex Generalis, dan Mahkamah Agung dapat melakukan uji materil terhadap Qanun.

Di dalam Qanun Nomor 5 Tahun 2011 Tentang Tata Cara Pembentukan Qanun disebutkan di dalam Pasal 3 materi muatan Qanun mengandung asas (Qanun Nomor 5 Tahun 2011):

1. Dinul islam

2. Sejarah aceh

3. Kebenaran

4. Kemamfaatan

5. Pengayoman 
6. Hak asasi manusia

7. Kebangsaan

8. Kekeluargaan

9. Keterbukaan dan komunikatif

10. Keanekaragaman

11. Keadilan

12. Keserasian dan nondiskriminasi

13. Ketertiban dan kepastian hukum

14. Kesamaan kedudukan dalam hukum dan pemerintahan

15. Keseimbangan, kesetaraan dan keselarasan

Materi muatan Qanun adalah seluruh materi muatan dalam rangka penyelenggaraan pemerintahan Aceh sesuai dengan Mou Helsenki 15 Agustus 2005 dan Undang-undang Nomor 11 Tahun 2006 Tentang Pemerintahan Aceh, kecuali dalam hubungan luar negeri, pertahanan luar (TNI), keamanan dalam negeri (Polisi), moneter dan fiskal, kekuasaan kehakiman dan urusan tertentu dalam bidang agama, (Qanun Nomor Tahun 2011).

Dalam uraian tersebut maka dapat disimpulkan bahwa Qaun dibuat karena ada perintah dari Undang-undang Nomor 11 Tahun 2006 Tentang Pemerintahan Aceh dan juga sumber hukum yang utama Undang Undang Dasar 1945 Pasal 18B.

\section{C.III. Wewenang Penetapan Sanksi Administrasi Pada Qanun}

\section{Wewenang Pemerintah Daerah Dalam Penetapan Sanksi}

Pasal 18 Undang-Undang Dasar 1945 merupakan dasar hukum penyelenggaraan otonomi daerah dengan memberikan kewenangan yang luas, nyata dan bertanggungjawab kepada daerah. Kepada daerah-daerah yang disebut daerah otonom, oleh Pemerintah Pusat diberi wewenang yang luas untuk mengurus rumah tangganya sendiri, terkecuali wewenang dalam bidang politik luar negeri, pertahanan dan keamanan, peradilan, moneter dan fiskal, Rozali Abdullah (2003 hal 18).

Menurut kamus Bahasa Indonesia kata kewenangan mengandung arti hal wewenang dan hak dan kekuasaan yang dimiliki untuk melakukan sesuatu. Sedangkan kata wewenang mengandung arti, :

1. Hak dana kekuasaan untuk bertindak

2. Kekuasaan membuat keputusan, memerintah, dan melimpahkan tanggung jawab kepada orang lain 
Penggunaan hukum administrasi sebagai sarana penegakan peraturan dalam Peraturan Daerah/Qanun dicantumkan dan ditentukan secara tegas dalam peraturan perundang-undangan bidang admnistrasi tertentu. Secara umum dikenal beberapa macam sanksi dalam hukum administrasi, yaitu, Sri Sundari Rangkuti ( 1996 hal 192-193):

1. Paksaan pemerintahan (bestuursdwang)

2. Penarikan kembali keputusan yang menguntungkan (izin, subsidi, pembayaran dan sebagainya)

3. Pengenaan uang paksa oleh pemerintah

4. Penggenaan denda administratif

Semua sanksi tersebut tidak selalu dapat diterapkan secara keseluruhan pada suatu bidang administrasi Negara tertentu. Sanksi paksaan pemerintahan misalnya, sudah barang tentu tidak dapat diterapkan dalam bidang kepegawaian dan ketenagakerjaan. Akan tetapi, dapat terjadi dalam suatu bidang administrasi diterapkan lebih dari keempat sanksi tersebut, seperti dalam bidang lingkungan.

\section{Efektivitas Penerapan Sanksi Administrasi Dalam Qanun Tidak Berjalan Efektif}

Ada beberapa hal yang menyebabkan penarapan sanksi administrasi di dalam Qanun Kota Banda Aceh tidak berjalan efektif, diantaranya adalah sebagai berikut, Wawancara Prof Husni Jalil (2013). :

1. Penegakan hukum, penegakan hukum yang dapat dilakukan dengan baik dan efektif merupakan salah satu tolak ukur keberhasilan suatu Negara dalam upaya mengangkat harkat dan martabat bangsanya di bidang hukum terutama dalam memberikan perlindungan hukum terhadap warganya. Hal ini berarti pula adanya jaminan kepastian hukum bagi rakyat, sehingga rakyat merasa aman dan terlindungi hak-haknya dalam menjalani kehidupan. Sebaliknya, penegakan hukum yang tidak berjalan sebagaimana mestinya merupakan indikator bahwa Negara yang bersangkutan belum sepenuhnya mampu memberikan perlindungan hukum kepada warganya. Mengingat begitu pentingnya penegakan hukum tersebut, problematika dan faktor-faktor yang mempengaruhinya khususnya dalam penegakan sanksi administrasi di dalam Qanun Kota Banda Aceh. Bila membicarakan efektifitas hukum dalam masyarakat berarti membicarakan daya kerja 
hukum itu dalam mengatur dan/atau memaksa masyarakat untuk taat terhadap hukum. Efektivitas hukum yang dimaksud berarti mengkaji kaidah hukum yang harus memenuhi syarat, yaitu berlakunya secara yuridis, sosiologis dan secara filosofis. Oleh karena itu faktor-faktor yang dapat mempengaruhi hukum itu berfungsi dalam masyarakat adalah kaidah hukum/peraturan itu sendiri, petugas/penegak hukum, sarana atau fasilitas yang digunakan oleh penegak hukum dan yang terakhir kesadaran masyarakat.

2. Koordinasi kurang antara Dewan Perwakilan Rakyat Kota dan eksekutif, diamana kurangnya koordinasi menyebabkan peraturan yang dilahirkan sering terhambat dalam hal pelaksanaan dan tidak ada koordinasi tersebut menyebabkan peraturan itu tidak berjalan sebagaimana mestinya di dalam masyarakat.

3. Belum turunnya peraturan walikota sebagai peraturan pelaksana, ada beberapa Qanun Kota Banda Aceh yang belum berjalan efektif dikarenakan peraturan walikota belum keluar sehingga Qanun tersebut tidak efektif di dalam penerapannya.

\section{Kesimpulan dan Saran}

\section{Kesimpulan}

Pembahasan terhadap permasalahan yang telah dikemukakan dalam tesis ini, maka kesimpulan yang dapat dikemukakan adalah sebagai berikut :

a. Dalam pemerintahan islam penguasa memiliki wewenang mengatur kepentingan umum untuk mencapai kemaslahatan dan terhindar dari segala kemudratan, dalam batas-batas yang ditentukan oleh syarat dan kaidah-kaidah umum yang berlaku sekalipun upaya ini tidak sejalan dengan "ijtihad ulama". Seiring denga luasnya ruang lingkup dan keragaman bidang urusan pemerintahan yang masing-masing bidang itu diatur dengan peraturan tersendiri, pada umunya macam-macam dan jenis sanksi itu dicantumkan dan ditentukan secara tegas dalam peraturan perundang-undangan bidang administrasi tertentu. Secara umum dikenal beberapa macam sanksi dalam hukum administrasi, yaitu paksaan pemerintah, penarikan kembali keputusan yang menguntungkan (izin subsidi, pembayaran dan sebagainya), pengenaan uang paksa oleh pemerintah, pengenaan denda administrasi. Macam-macam sanksi tersebut 
tidak selalu dapat diterapkan secara keseluruhan pada suatu bidang administrasi Negara tertentu. Sanksi paksaan pemerintahan misalnya, sudah barang tentu tidak dapat diterapkan dalam bidang kepegawaian dan ketenagakerjaan. Akan tetapi, dapat terjadi dalam suatu bidang administrasi diterapkan lebih dari kempat macam sanksi tersebut, seperti dalam bidang lingkungan.

b. Qanun merupakan salah satu bentuk hukum tertulis dalam sistem perundang-undangan nasional, yang sejenis dengan Peraturan Daerah. Numum secara khusus isinya berbeda, oleh karena kewewenangan mengatur dan materi muatan tertentu dalam qanun didasarkan pada ketentuan dalam Undang-Undang No. 11 Tahun 2006. Sedangkan materi muatan "peraturan daerah" yang secara umum berpedoman pada ketentuan Undang-Undang No. 32 Tahun 2004. Kebijakan untuk konsep sanksi administrasi dalam qanun menurut penjelasan Undang-undang Nomor 11 Tahun 2006 Tentang Pemerintahan Aceh menyebutkan Qanun adalah peraturan yang dapat mengeyampingkan peraturan perundangundangan yang lain dengan mengikuti asas Lex Specialis derogaat Lex Generalis.

c. Pasal 18 Undang-Undang Dasar 1945 merupakan dasar hukum penyelenggaraan otonomi daerah dengan memberikan kewenangan yang luas, nyata dan bertanggungjawab kepada daerah. Kepada daerah-daerah yang disebut daerah otonom, oleh Pemerintah Pusat diberi wewenang yang luas untuk mengurus rumah tangganya sendiri, terkecuali wewenang dalam bidang politik luar negeri, pertahanan dan keamanan, peradilan, moneter dan fiskal. Dalam perumusan Pasal 18 Undang-Undang Dasar 1945, yang diartikan secara luas adalah "pemerintahan daerah" yang mencakup juga fungsi legislatif di daerah, sedangkan yang diartikan secara sempit adalah "pemerintahan daerah" yang hanya mencakup cabang eksekutif saja, yaitu Gubernur, Bupati atau Walikota beserta perangkat daerah sebagai unsur penyelenggara pemerintahan daerah. Kedaulatan pemerintahan dalam suatu Negara yang berbentuk kesatuan dapat diselenggarakan dengan cara terhinpun/ditumpuk (gathered) secara sentralisasi (centralized), sehingga segala urusan dalam Negara terletak di tangan pemerintah pusat (central government), dan semua kewenangan pemerintahan dilakukan oleh satu pusat pemerintahan (sigle centralized government), atau oleh pusat bersama-sama dengan organnya yang berada/dipencarkan di daerah-daerah. Penyelenggaraan pemerintahan 
yang dipencarkan di daerah-daerah dilakukan sebagai akibat dari tuntuan demokrasi, efisiensi dan efektivitas pemerintahan. Pelaksanaan pemerintahan itu didasarkan pada asas dekonsentrasi dan desentralisasi. Baik dekonsentrasi maupun desentralisasi merupakan metode-metode dalam pendistribusian kekuasaan pemerintahan atas dasar wilayahwilayah tertentu. Dekonsentrasi menimbulkan wilayah administratif sedangkan desentralisasi menciptakan daerah otonom.

\section{Saran}

Setelah melakukan pembahasan dan analisa terhadap permasalahan yang telah dikemukakan dalam tesis ini, saran yang dapat diberikan oleh penulis adalah sebagai berikut :

1. Pengaturan sanksi administrasi pada Qanun Kota Banda Aceh harus sesuai dengan tujuan hukum administrasi Negara. Tujuan hukum administrasi Negara yaitu memberikan perlindungan terhadap rakyat atau badan hukum perdata dari tindakan sewenang-wenang pejabat administrasi Negara.

2. Dari Pasal 84 ayat (1) dan (2) yang menjadi unsur-unsur Pasal yang tidak sesuai dengan tujuan hukum administrasi Negara adalah ketidaksesuaian bunyi Pasal yang terdapat dalam Qanun Nomor 6 Tahun 2010 Kota Banda Aceh. Berdasarkan hal tersebut Penulis menyarankan agar pembuat undang-undang dapat memperbaiki pengaturan, serta lebih memperhatikan bunyi pasal-pasal di dalam Qanun.

3. Di dalam merancang Qanun penulis menyarankan agar Qanun yang akan dirancang dapat benar-benar bisa diterapkan di dalam masyarakat, sehingga tidak ada Qanun yang terkesan dipaksakan. Penulis berharap masyarakat juga dapat ikut berpartisipasi dalam pembuatan Qanun dan koordinasi antara Legislatif dan Eksekutif benar-benar terjalin sebagaimana mestinya. 


\section{DAFTAR PUSTAKA}

\section{A. Buku-buku}

Ablisar, Madiasa, Hukuman Cambuk Sebagai Alternatif Pemidanaan Dalam Rangka Pembaharuan Hukum Pidana Indonesia, Medan : USU Press, 2011

Anwar Saiful dan Marzuki Lubis, Sendi-Sendi Hukum Administrasi Negara, Medan : Gelora Madani Press, 2004

Abdullah, Rozali, Pelaksanaan Otonomi Luas dan Isu Federalisme Sebagai Suatu Alternatif, Jakarta : PT Raja Grafindo Persada, 2003

Basyar, M. Hamdan, et.al, Aceh Baru Tantangan Perdamaian dan Reintegrasi, Yogyakarta : Pustaka Pelajar, 2008

Dahlan, Abdul Aziz, et, al, Ensiklopedi Hukum Islam Jilid 5, Jakarta : PT Ichtiar Baru Van Houve, 1996

Hadjon, Philipus M, et.al, Pengantar Hukum Administrasi Indonesia, Yogyakarta : Gadjah Mada University Press, 2011

Juanda, Hukum Pemerintah Daerah, Pasang Surut Hubungan Kewenangan Antara DPRD dan Kepala Daerah, Bandung : PT Alumni, 2004

Latief, Abdul, Hukum dan Peraturan Kebijaksanaan (beleidsregel) Pada Pemerintahan Daerah, Yogyakarta : UII Press, 2005

Manan, Bagir, Sistem dan Teknik Pembuatan Peraturan Perundang-undangan Tingkat Daerah, Bandung : LPPM-UNISBA, 1995

Muslimin, Amran, Beberapa Asas dan Pengertian Pokok Tentang Administrasi dan Hukum Administrasi, Bandung : Alumni, 1985

Rangkuti, Siti, Hukum Lingkungan dan Kebijaksanaan Lingkungan Nasional, Surabaya : Airlangga University Press, 1996

Ridwan, Juniarso dan Achmad Sodik Sudrajat, Hukum Administrasi Negara dan Kebijakan Pelayanan Publik, Bandung : Nuansa, 2010

Said, Mohammad, Aceh Sepanjang Abad Jilid I, Medan : Harian Waspada Medan, 2007

Widjaja, HAW, Penyelenggaraan Otonomi Di Indonesia Dalam Rangka Sosialisasi Undang-undang Nomor 32 Tahun 2004 Tentang Pemerintahan Daerah, Jakarta : Raja Grafindo Persada, 2005

Yuliandri, Asas-Asas Pembentukan Peraturan Perundang-undangan Yang Baik, Gagasan Pembentukan Undang-Undang Berkelanjutan, Jakarta : PT Raja Grafindo Persada, 2011 


\section{B. Peraturan Perundang-undangan}

Undang-Undang Dasar Tahun 1945

Undang-undang Nomor 12 Tahun 2011 Tentang Pembentukan Peraturan Perundang-undangan

Undang-undang Nomor 12 Tahun 2008 Tentang Perubahan Kedua atas Undangundang Nomor 32 Tahun 2004 Tentang Pemerintah Daerah

Undang-undang Nomor 11 Tahun 2006 Tentang Pemerintahan Aceh

LAN Republik Indonesia, Pengaturan dan Penegakan Hukum Dalam Sistem Administrasi Negara, Jakarta : LAN RI, 2007

Qanun Nomor 5 Tahun 2011 Tentang Tata Cara Pembentukan Qanun Aceh

Peraturan Daerah Nomor 6 Tahun 2005 Tentang Berpakaian Muslim dan Muslimah Kabupaten Solok Selatan

Nota Kesepahaman Antara Pemerintah Republik Indonesia dan Gerakan Aceh Merdeka, Helsenki, Finlandia, Senin 5 Agustus 2005

\section{Internet}

http://datafilecom.blogspot.com/2010/03/makalah-tentang-qanun.html, di akses pada hari senin tanggal 18 Februari 2013, pukul 12.30 WIB

\section{Makalah/Disertasi/Karya Ilmiah}

Faisal A. Rani, Kedudukan Qanun Dalam Sistem Perundang-undangan, Makalah Yang Disampaikan Pada Muzakarah Majelis Permusyawaratan Ulama (MPU) Aceh, Banda Aceh, 3 Desember 2009

Faisal A. Rani dan Mahdi Syahbandir, Praktek-praktek Hukum Administrasi Negara Dalam Penyelenggaraan Pemerintahan Baik Pusat Maupun Daerah, Kanun Jurnal Ilmu Hukum No 46 Edisi April 2009, Banda Aceh

Husni Jalil, Kedudukan Qanun Dalam Peraturan Perundang-undangan, Disampaikan Dalam Kegiatan Pembinaan Politik Bagi Ormas/LSM, Tokoh Masyarakat, Pimpinan Pasantren Tingkat Provinsi Aceh, September 2005

Husni Jalil, Rapat Permusyawaratan dan Pemeriksaan Pendahuluan Dalam Penyelesaian Sengketa Administrasi Negara, Jurnal Transformasi Administrasi, Banda Aceh, 2011

Hasnan, Tesis Mengenai Peraturan Ketentuan Sanksi Pidana Dalam Pemerintah Daerah, Medan, 2012 
Mohd Daud Yoesoef, Qanun Sebagai Aturan Pelaksana Peraturan Perundangundangan atasan, Kanun Jurnal Ilmu Hukum No 47 Edisi Agustus 2009, Banda Aceh

Sulaiman, Membentuk Hukum Bagi Perdamaian Aceh, Kanun Jurnal Ilmu Hukum No 56 Edisi April 2012, Banda Aceh 